\title{
Development of The Workplace Attachment Scale (WAtS): evidence of validity and reliability
}

\section{Desarrollo de The Workplace Attachment Scale (WAtS): evidencia de validez y confiabilidad}

\section{Desenvolvimento da The Workplace Attachment scale (WAtS): evidências de validade e confiabilidade}

\author{
Alexsandro Luiz De Andrade ${ }^{1}$, ORCID 0000-0003-4953-0363 \\ Pâmela Fardin Pedruzzi ${ }^{2}$, ORCID 0000-0003-0869-8602 \\ ${ }^{12}$ Post-Graduation Program in Psychology, Federal University of Espírito Santo. Brazil
}

\begin{abstract}
Attachment refers to affective-emotional bonds developed early between child and caretaker, and to its consequences throughout life. This study aimed at constructing a measure to assess adult attachment in workplace relationships. The sample of the study consisted of 450 adult participants $(62.2 \%$ female; $M=24$ years old, $S D=6.69 \%)$ included in the labor market. The results of an exploratory and confirmatory factor analysis indicated a three-dimensional structure that evaluated aspects of security, anxiety and avoidance of attachment in workplace situations, explaining $55 \%$ of the total variance. In addition, dimensions in both analyses showed omega coefficients high than .80. The measure presented expected correlations with close attachment, career success, satisfaction with life and self-efficacy dimensions. In conclusion, this study offers a validated measure: The Workplace Attachment Scale (WAtS), in Brazilian Portuguese that enables the investigation of attachment relationships in the workplace.
\end{abstract}

Keywords: attachment; interpersonal relationships; work; psychological test; psychological assessment

Resumen: El apego se refiere a los vínculos afectivos-emocionales desarrollados tempranamente entre el niño y el cuidador, junto a sus consecuencias a lo largo de la vida. Este estudio tuvo como objetivo construir una medida para evaluar el apego adulto en las relaciones laborales. La muestra de estudio consistió en 450 participantes adultos $(62.2 \%$ mujeres; $M=24$ años, $D E=6.69 \%$ ) que se encuentran en el mercado laboral. Los resultados del análisis factorial exploratorio indicaron una estructura tridimensional, explicando el $55 \%$ de la varianza total. Las dimensiones en ambos análisis mostraron coeficientes omega superiores a .80. La medida presentó correlaciones esperadas con las dimensiones del apego cercano, el éxito profesional, la satisfacción con la vida y la autoeficacia. En conclusión, este estudio ofrece una nueva medida: The Workplace Attachment Scale (WAtS), en portugués brasileño, que permite la investigación de las relaciones de apego en el lugar de trabajo.

Palabras clave: apego; relaciones interpersonales; trabajo; test psicológico; evaluación psicológica 
Resumo: O apego refere-se aos laços afetivo-emocionais desenvolvidos precocemente entre a criança e o cuidador e às suas consequências ao longo da vida. Este estudo teve como objetivo construir uma medida para avaliar o apego de adultos nas relações de trabalho. A amostra de estudo foi composta por 450 participantes adultos (62,2\% do sexo feminino; $M=24$ anos, $D P=$ $6,697 \%$ ), que se encontram inseridos no mercado de trabalho. Os resultados da análise fatorial exploratória indicaram uma estrutura tridimensional, explicando $55 \%$ da variância total. As dimensões em ambas as análises mostraram coeficientes ômega superiores a 0,80. A medida apresentou correlações esperadas com as dimensões de apego próximo, sucesso na carreira, satisfação com a vida e autoeficácia. Em conclusão, este estudo oferece uma medida validada, a The Workplace Attachment Scale (WAtS), em português brasileiro, que possibilita a investigação das relações de apego no ambiente de trabalho.

Palavras-chave: apego; relacionamento interpessoal; trabalho; psicometria; teste psicológico; avaliação psicológica

Received: 08/05/2019

Accepted: 09/22/2020

How to cite:

De Andrade, A.L., \& Pedruzzi, P. F. (2020). Development of The Workplace Attachment Scale (WAtS): evidence of validity and reliability. Ciencias Psicológicas, 14(2), e-2298. doi: https://doi.org/10.22235/cp.v14i2.2298

Correspondence: Alexsandro Luiz De Andrade, Av. Fernando Ferrari, 514, 29075-910 - Vitória - ES, Brasil. Email: alexsandro.deandrade@yahoo.com.Pâmela Fardin Pedruzzi,e-mail: pamfardin@hotmail.com

Bowlby (1973) defined attachment as a psychological aspect that refers to affectiveemotional bonds established among individuals. Researches has demonstrated that attachment models are predictors of important interpersonal aspects like well-being, interpersonal behavior and life quality (Harms, 2011). Attachment theory assumes that the way caretakers respond to infants determines their attachment style. Responsive and consistent caretakers promote secure attachment style development, while non-responsive and inconsistent ones promote anxious or avoidant styles, like insecurity attachment (Hazan \& Shaver, 1990; Yip, Ehrhardt, Black \& Walker, 2017).

Anxious attachment pattern is characterized by fear in the exploration of the environment (Leiter, Day \& Price, 2015). In adults, this pattern characterizes individuals who are more dependent on others, insecure and has high level of rejection. Avoidant pattern is characterized by avoidance of proximity contact and close relationships (De Andrade, Oliveira, Knowles, Neto \& Hatfield, 2018). Also, comprehend the use of cognitive and emotional deactivation strategies by the suppression of bonding feelings in relevant attachment situations by adults. Secure attachment in adult's individuals is characterized from patterns of showing comfort with proximity to their partners, maintaining appropriate boundaries, developing trust, presenting long-lasting relationships and seeking support when necessary (Dahling \& Librizzi, 2015).

There is evidence that adult attachment style correlates with a variety of outcomes. For example, adult insecure attachment is related to the presence of lower satisfaction in romantic relationships (Gleeson \& Fitzgerald, 2014), depression (Conradi, Kamphuis \& de Jonge, 2017), low parenting self-efficacy (Kohlhoff \& Barnett, 2013), risk of parental maltreatment (Brown, 
Harris \& Craig, 2019), among other interpersonal problems (Hayden, Müllauer \& Andreas, 2017).

More recently, researchers have been showing interest on implications of adult attachment styles to relationships and performance in the workplace (De Andrade et al., 2018; Leiter, Peck, \& Gumuchian, 2015; Yip et al., 2017). During career decision making, securely attached people presented higher self-efficacy, career planning confidence, less fear of commitment, higher engagement in the selection and implementation of a career plan, and less career indecision (Bolat \& Odac1, 2017; Kvitkovičová, Umemura \& Macek, 2017; Poncy, Kim, Ramos \& Lopez, 2017). At the workplace, securely attached people showed greater levels of confidence and mastery, higher levels of job satisfaction, vocational adjustment and adaptive relationships. The presence of more ethical values and beliefs and fewer propensities to transgress the norms reduced the impact of job insecurity outcomes (Jiang, 2017; Phang, Fan \& Arbona, 2018; Ronen \& Zuroff, 2017).

On the other hand, insecure attachment has been demonstrated to be related with negative outcomes as decreased job satisfaction, engagement and turnover intentions (Byrne, Albert, Manning \& Desir, 2017; Dahling \& Librizzi, 2015). Insecure anxious attachment was related to high workplace incivility, exhaustion and cynicism and preference for external, temporary contracts (Albert \& Horowitz, 2009; Leiter et al., 2015). Insecure avoidant attachment was negatively related to positive social constructs (civility, psychological safety, trust) (Leiter, Peck \& Gumuchian, 2015).

Research assessing attachment and workplace environment has also shown burnout implications between anxious attachment and job performance (Vîrgă, Schaufeli, Taris, van Beek \& Sulea, 2018); relationship between group cohesion, sense of security and anxious attached people (Reizer, Oren \& Hornik, 2019); association between insecure attachment styles and work-family conflict construct (De Andrade et al., 2018); and self-compassion as a mediator between individual attachment dimensions and organizational outcomes (Reizer, 2019).

There are few adult attachment measures in the workplace context (Leiter et al., 2015; Vîrgă et al., 2018). Most of the attachment measures are developed to assess attachment in familiar and romantic contexts and these measures usually evaluate two or three attachment dimensions. However, bidimensional models were frequently citated in studies (De Andrade et al., 2018; Leiter et al., 2015; Natividade \& Shiramizu, 2015). Instruments in this model includes items designed to measure two insecure dimensions of attachment, anxiety and avoidance (Brennan, Clark \& Shaver, 1998). No measures were found to evaluate the original threedimensional model of security and insecurity (anxiety and avoidance).

To evaluate attachment aspects in workplace context, Leiter et al. (2015) developed for Canadian context, The Short Workplace Attachment Measure (SWAM), a 10-item measure assessing attachment relations in the context of workplace environment based on the bidimensional model. SWAM presented two expected subscales, that were uncorrelated with each other and had acceptable internal Cronbach consistency (.75 and .78 , respectively).

Considering the ongoing interest for studying aspects of attachment in the workplace and the current empirical orientation towards the development of contextual specific measures of attachment (Fraley, Hudson, Heffernan \& Segal, 2015), the present study aimed to develop a new measure to assess adult attachment in the workplace. It is important to mention that none of the measures noticed assesses the original nature of the attachment construct and only one instrument that assess attachment in the workplace was found (Leiter et al., 2015). Additionally, this study explored the scale's fit to a model with three dimensions (security, anxious and avoidant), along with convergent and divergent validity with the constructs of adult romantic attachment, self-efficacy and career adaptability. 


\section{Study hypothesis}

Considering that attachment styles are structured from the individual's first experiences with their caregiver and its modulation has an impact on health, social life, romantic relationships and work variables (De Andrade et al., 2018; Hazan \& Shaver, 1990; Leiter et al., 2015); along with the two-dimensionality proposed by ECR scale (Brennan et al., 1998; Natividade \& Shiramizu, 2015) which operationalizes the assessment of adult attachment in romantic relationships through dimensions of anxious and avoidant attachment, it is estimated that: ECR's avoidant attachment dimension will associate positively with Wat-S's avoidance attachment (H1.1). Furthermore, ECR's anxious attachment dimension will positively associate with its parallel dimension in WAt-S (H1.2). Both avoidant and anxious attachment from ECR will negatively associate with WAt-S secure attachment aspects (H1.3). Demonstrating the extent of individual attachment characteristics of the romantic context to relational aspects of work.

Regarding the relationship with the self-efficacy construct, understood as a personal belief of competence and efficiency (Teixeira, Dias \& Dell'Aglio, 2012), it is estimated that: secure attachment measured by WAt-S, preserving characteristics like comfort with interpersonal relationships (Ramos \& Lopez, 2018) and safety in exploring workplace activities (Dahling \& Librizzi, 2015) will be positively associated with self-efficacy (H2.1); and both dimensions of insecure attachment (anxious and avoidant), characterized by insecurity in exploring the environment and inconsistent bonding relationships (Ramos \& Lopez, 2017), will be negatively associated with self-efficacy (H2.2)

Finally, considering career adaptability as an individual measure associated with adaptation and transition resources for professional development coping (Savickas, 2011), it is estimated that secure attachment dimension evaluated for Wat-S and characterized for a positive self-esteem, relationship comfort, and positive view of yourself (Dahling \& Librizzi, 2015; Hazan \& Shaver, 1990), will be associated positively with control, curiosity, confidence and adaptability competence aspects (H3.1). In turn, it is expected that insecurity (anxiety and avoidance) attachment, conserving attributes like lower self-esteem and apprehension in exploration of life and professional aspects (Hazan \& Shaver, 1990; Yip et al., 2017), will associate negatively with the four adaptability domains (H3.2).

\section{Method}

\section{Participants}

The sample consisted of 450 adult participants (62.2\% female), most from Brazil's southeast (Espírito Santo, Rio de Janeiro and São Paulo). Mean participant's age was 24 years old $(S D=6.69 \%)$. Of these, 345 had graduated, 36 had high school degree and 27 had postgraduate degree. About race/ethnicity, 226 were self-declared white, 178 brown (mixed), 33 black and 13 others. All participants of the study declared that had a job position in the labor market at moment of data collection. To conduct the data analysis, the participants were divided into two equal groups of 225 individuals (the first one for exploratory factor analysis and the second one for confirmatory analysis).

\section{Procedure for developing the Workplace Attachment Scale (WAtS)}

The WAtS construction process was guided by general guidelines for the adaptation and development of psychometric instruments (Borsa, Damásio \& Bandeira, 2012; ITC, 2017). 
Procedure was synthesized in 5 steps. Initially, a search for instruments that measures adult attachment was conducted and one instrument was used as operational guidance for the definition of the construct and source of items, namely ECR-Brazil (Natividade \& Shiramizu, 2015). Then, using the definitions of avoidance and anxious attachment of the available measures, the authors made adaptations in the phrasal structure of the items, adjusting ERC-R's items from the romantic relationship context, redirecting them to a work context.

Next, new items were developed by the researchers, especially for the security attachment dimension, where all the new items were written aiming a direct evaluation of security attachment characteristics (e.g. I fell that I can trust my work colleagues). An evaluation of the items and answer key of the instrument was carried out: 10 participants with a profile of the target population ( 5 men and 5 women) assessed aspects of clarity, comprehension and content of the items. Later, after semantic adjustments and qualitative tests of the preliminary version of the instrument, psychometric aspects were tested in the target sample of the study. A total set of 30 items was proposed and Table 1 presents the elaboration process and sample items.

Table 1

Elaboration process of the WAtS

\begin{tabular}{ccl}
\hline Origin of items & Quant. items & Example \\
\hline Adapt. ECR-R/Brazil & 5 & $\begin{array}{l}\text { Original item: Geralmente, tento evitar muita } \\
\text { proximidade afetiva com meu }(\text { minha) parceiro }(a)\end{array}$
\end{tabular}

Modified version: Procuro evitar muita proximidade afetiva com meus colegas de trabalho. (Av.)

Created by the authors $\quad 30 \quad$ Original item: Tenho dificuldades em reconhecer $a$ qualidade de meu trabalho mesmo quando sou elogiado. (A)

Legend: ECR-R-Brazil (Natividade \& Shiramizu, 2015); A(anxious); Av.(avoidant).

\section{Instruments}

The data collection survey was composed of different psychological scales and sociodemographic questions to characterize the sample (e.g. sex, age, region of residence, educational level and work aspect questions). The scales used in the study were:

a) Experience in Close Relationship Scale (short Version) (Natividade \& Shiramizu, 2015), a 10-item 5-point Likert scale (1-not at all like me/5-very much like me) that evaluates romantic attachment. It comprises two subscales: anxiety $(\alpha=.73$; e.g. Often, I think that my partner does not want as much emotional proximity/closeness as I would like) and avoidance ( $\alpha=$ .73; e.g. Generally, I try to avoid a lot of emotional closeness with my partner).

b) Self-efficacy scale (Meneses \& Abbad, 2010), 9-item 5-point Likert scale (1-strongly disagree/5-strongly agree) assessing the positive dimension of self-efficacy ( $\alpha=.79$; e.g. I trust my skills).

c) Career Adapt-Abilities Scale (Audibert \& Teixeira, 2015), instrument composed of 24 items that assess adaptability dimensions: control $(\alpha=.89$; e.g. Making decisions by myself), confidence ( $\alpha=.83$; e.g. Learning new skills), $(\alpha=.78$; e.g. Preparing for the future) and curiosity ( $\alpha=0.87$; e.g. Looking for opportunities to grow). The items were answered on a five-point Likert scale (1 - I developed little or nothing at 5 - I developed extremely well).

d) The version of the Workplace Attachment Scale (WAtS) developed for this occasion. 


\section{Procedures of Data collection}

Data were collected online with personal recruitment using CORP method (Wachelke, Natividade, De Andrade, Wolter \& Camargo, 2014) and personalized invitations via e-mail and social media. Following CORP's guidelines, after identifying potential participants, research assistants sent a brief message detailing the study and inviting to participate. Those who accepted received a second message with a link to access the online form. Then, informed consent was presented to them, It, adapted for use on the web, included information about the research and instructions to complete the questionnaire or stop participating. Average answering time was about 20 minutes.

\section{Ethical considerations}

This work derived from a broader project reviewed by the Ethics Committee of the Federal University of Espírito Santo under the number 38697914.8.0000.5542. Participants were fully informed about the study's objectives and consented to participate in accordance to the National Health Council's Resolution $n^{\circ}$ 466/12 regarding Guidelines and Standards for Researches Involving Human Beings (CONEP, 2014).

\section{Procedures of data analysis}

Data were analyzed with support of Factor (Lorenzo-Seva \& Ferrando, 2013) and Mplus (Muthén \& Muthén, 2012). First, data matrix was examined with a goal to detect the presence of lost cases. Consequently, were evaluated the assumption of normality of the items by calculating the size of the asymmetry and kurtosis. Due to the ordinal nature of the data, the factorial structure of the scale was explored by means of Exploratory Factor Analysis (EFA) in a sample of 225 participants. A parallel analysis with promin rotation was performed, using the Unweighted Least Squares (ULS) based on a matrix of polychoric correlations in order to achieve the number of dimensions recommended for the scale.

To evaluate the best structure for the new attachment scale, the model from EFA were tested with 225 participants with a confirmatory factorial analysis (CFA) using the estimator weighted least square mean and variance adjusted (WLSMV). The fit indicator's used to assess the adequacy of the models were: $\chi^{2} / d f$, with smaller values to find a better fit to the model (Rindskopf, 2010); Comparative Fit Index (CFI) higher than 90 (Jackson, Gillaspy \& PurcStephenson, 2009); Root mean-square error of approximation (RMSEA) inferior than 0.8 and the Standardized Root-Mean Residual (Schmitt, 2011) be inferior to 0.10, expecting lower values to find a better fit to the respective model (Rindskopf, 2010). Omega coefficient were tested in both analyses to identify the dimension's internal consistency. After computing mean scores to all constructs, we conducted correlations (Pearson's $r$ ) analysis to test the external validity of the Workplace Attachment Scale.

\section{Results}

\section{Exploratory factor analysis}

Seeking to find the adequacy of the data for factor analysis, the Kaiser-Meyer-Olkin $(\mathrm{KMO})$ and Bartlett's sphericity test indexes were significant $\left[\mathrm{KMO}=0.80\right.$; Bartlett, $\chi^{2}(325)=$ 4013.8; $p<.001]$. Then, using the software Factor, the New Workplace Attachment Scale set of items were submitted to EFA based on a parallel analysis with a polychoric correlation matrix to identify the number of dimensions. The analysis suggested three dimensions, indicating 
similarity with original model based on the attachment theory. Table 2 indicates the variance established by empiric and random values generated by parallel analysis. As shown, only after the third component was observed, the eigenvalue was greater than the empirical.

Table 2

Empiric and random eigenvalues of the first eight components generated by parallel analysis

\begin{tabular}{ccccccccc}
\hline & \multicolumn{1}{c}{ Components } \\
\cline { 2 - 9 } Variance & 1 & 2 & 3 & 4 & 5 & 6 & 7 & 8 \\
\hline Empiric & 24.56 & 21.48 & 9.80 & 6.24 & 5.04 & 4.15 & 3.83 & 2.95 \\
Random & 9.76 & 8.94 & 8.34 & 7.80 & 7.30 & 6.85 & 6.40 & 5.86 \\
\hline
\end{tabular}

In sequence, an exploratory factor analysis was performed to extract a three-dimensional model with an Unweighted Least Squares (ULS) estimator and a promin Rotation was considered. The dimensional structure of the WAtS found is presented on table 3.

Table 3

Work Attachment Scale's items and factorial loadings in the dimensions

\begin{tabular}{|c|c|c|c|}
\hline Item & Anx. Att. & Sec. Att. & Avo. Att. \\
\hline item 1 & .83 & & \\
\hline item 2 & .66 & & \\
\hline item 3 & .69 & & \\
\hline item 4 & .65 & & \\
\hline item 5 & .75 & & \\
\hline item 6 & .50 & & \\
\hline item 7 & .81 & & \\
\hline item 8 & .80 & & \\
\hline item 9 & .84 & & \\
\hline item 10 & .84 & & \\
\hline item 11 & 63 & & \\
\hline item 12 & 66 & & \\
\hline item 13 & 60 & & \\
\hline item 14 & & .77 & \\
\hline item 15 & & .77 & \\
\hline item 16 & & .86 & \\
\hline item 17 & & .79 & \\
\hline item 18 & & .69 & \\
\hline item 19 & & .62 & \\
\hline item 20 & & .60 & \\
\hline item 21 & & .59 & \\
\hline item 22 & & .58 & \\
\hline item 23 & & .54 & \\
\hline item 24 & & & .94 \\
\hline item 25 & & & .92 \\
\hline item 26 & & & .71 \\
\hline item 27 & & & .43 \\
\hline item 28 & & & .39 \\
\hline item 29 & & & .36 \\
\hline Total & 13 & 10 & 6 \\
\hline Factor variance $(\%)$ & $28 \%$ & $19 \%$ & $9 \%$ \\
\hline Omega coefficient & .92 & .88 & .80 \\
\hline
\end{tabular}


Of the total of 30 items, only one did not fit the proposed factor: "I consider myself safe with my work skills" therefore it was excluded from the final structure, totalizing in a 29 items scale. The full instrument can be seen in appendix A.

According to the analysis, factor 1 was composed by 13 items assessing insecure anxious attachment style in work relationships, including insecurity towards coworkers' support (e.g. I'm afraid that my coworkers will not help me when I need then to) and concern over not fulfilling others' expectations (e.g. I worry about not corresponding to my coworker's expectations). Factor 1 explained $28 \%$ of data variance and Omega coefficient of factor was .92 .

The second factor, secure attachment, was organized with 10 items that together represented aspects of trust, perception of support from boss and co-workers, as well perceived positive emotions in interactions with colleagues from the workplace (e.g. I feel that I can trust in my co-workers). Factor 2 explained $19 \%$ of data variance and Omega coefficient of factor was .88 .

Factor 3 was comprehended six items and assesses avoidant attachment style in work relationships, including lack of motivation to establish bonds at work (e.g. I seek to avoid too much affective proximity with my coworkers) and discomfort with coworker's proximity (e.g. I often feel concerned when my boss and/or work supervisor get overly near me). The fit index of three-factor model was: $x^{2} / d f=1.54$; $\mathrm{CFI}=.98, \mathrm{NNFI}=.97, \mathrm{AGFI}=.94$ and $\mathrm{RMSEA}=.04(.02-$ $.05)$.

\section{Confirmatory factor analysis}

Confirmatory factor analysis (CFA) was performed based on model from exploratory factor analysis. A sample of 225 individuals was considered through software Mplus (Muthén \& Muthén, 2012). Results demonstrated that not all fit indices showed a good adjustment for the model proposed by the exploratory factor analysis (Model 1). In an attempt to find a better adjustment for the scale, a second model was tested oriented by modification indices on each factor (anxious: e13-e12; avoidant: e17-e16; secure: e10-e14). Considering these suggestions, a new and better adjustment was obtained (Model 2). Table 4 shows fit indexes from both models investigated.

Table 4

Fit indexes from the tested models

\begin{tabular}{cccccc}
\hline Models & $\chi^{2} / \mathrm{Gl}$ & CFI & TLI & RMSEA & IC 90\% \\
\hline Model 1 & 3.48 & 0.90 & 0.89 & 0.10 & $0.10-0.11$ \\
Model 2 & 3.02 & 0.92 & 0.91 & 0.09 & $0.08-0.10$ \\
\hline
\end{tabular}

\section{Convergence and divergence among WAtS and other constructs}

Using a Pearson correlation analysis between the dimensions from the WAtS (security, anxiety and avoidance) and some associated constructs (closeness attachment styles, selfefficacy and career adaptability dimensions), convergent and divergent validity were investigated (Freitas \& Damásio, 2018). All correlations can be observed on Table 5. 
Table 5

Correlation matrix among dimensions from WAtS and convergent constructs

\begin{tabular}{|c|c|c|c|c|c|c|c|c|c|c|}
\hline Dimensions & 1 & 2 & 3 & 4 & 5 & 6 & 7 & 8 & 9 & 10 \\
\hline 1. W. Sec. & 1 & & & & & & & & & \\
\hline 2. W. Anx. & $.24^{* *}$ & 1 & & & & & & & & \\
\hline 3. W. Avo. & $-.26^{* *}$ & $.28^{* *}$ & 1 & & & & & & & \\
\hline 4. E. Anx. & $.10^{*}$ & $.42^{* *}$ & $.22^{* *}$ & 1 & & & & & & \\
\hline 5. E. Avo. & $-.33^{* *}$ & $-.18^{* * *}$ & .02 & -.09 & 1 & & & & & \\
\hline 6. S. effic. & $.13^{* * *}$ & $-.24^{* * *}$ & $-.15^{* *}$ & $-.19^{* *}$ & -.02 & 1 & & & & \\
\hline 7. A. Conc. & .06 & .00 & -.02 & -.06 & -.06 & $.46^{* *}$ & 1 & & & \\
\hline 8. A. Contr. & .09 & $-.22^{* * *}$ & $-.19^{* * *}$ & $-.09^{*}$ & -.01 & $.55^{* *}$ & $.53^{* *}$ & 1 & & \\
\hline 9. A. Curi. & .09 & $-.11^{*}$ & -.08 & -0.03 & .05 & $.43^{* *}$ & $.58^{* *}$ & $.62^{* *}$ & 1 & \\
\hline 10. A. Conf. & .05 & $-.21^{* *}$ & $-.10^{*}$ & $-.15^{* *}$ & -.01 & $.59^{* *}$ & $.59^{* *}$ & $.63^{* *}$ & $.64^{* *}$ & 1 \\
\hline
\end{tabular}

Legend: W. Sec. (WAtS security), W. Anx. (WAtS anxiety), W. Avo. (WAtS avoidance), E. Anx. (ECR anxiety), E. Avo. (ECR avoidance), S. effic. (Self-efficacy), A. Conc. (adaptability concern), A Contr. (adaptability control), A. Curi. (adaptability curiosity) and (adaptability confidence). ${ }^{*} p<.01 ; * * p<.001$ ).

Based on the correlation matrix presented, secure attachment positively correlated with anxiety attachment dimensions (WAtS; ECR) and self-efficacy. In addition, secure attachment negatively correlated with avoidance attachment (WAts; ECR). There were no correlations with career adaptability dimensions. Anxiety attachment measured by WAtS showed a positive and significant correlation with WAtS avoidance and ECR's anxious dimension. Negative and significant correlation was displayed with ECR's avoidance, self-efficacy and career dimensions of control and confidence.

\section{Discussion}

Overall results showed favorable evidence of the validity and accuracy for the Workplace Attachment Scale (WAtS). The resulting measure presented an adequate factorial structure according to the original three-dimensional theoretical proposition of John Bowlby's attachment (Collins \& Read, 1990; Ravitz, Maunder, Hunter, Sthankiya \& Lancee, 2010). In addition, WAtS also presented evidence of convergent and divergent validity with individual aspects of interpersonal domains (adult romantic attachment), self-efficacy and work outcomes (career adaptability). Finally, all dimensions showed positive omega reliability with indices greater than .81 .

From the exploratory and confirmatory factor analysis procedures, the set of previously elaborated items indicated adequate adjustment in the original structure of secure attachment, insecure anxious and insecure avoidant attachment. The resulting internal structure of WAtS is similar to that of other adult attachment scales, developed internationally for adult attachment assessment (Hazan \& Shaver, 1990; Ravitz et al., 2010).

The partial correspondence between dimensions of security, anxiety and avoidance measured by WAtS and attachment in the romantic relationship by ECR (Natividade \& Shiramizu, 2015) also indicates a continuity of attachment styles throughout contexts, as expected from attachment theory (Byrne et al., 2017; Hazan \& Shaver, 1990; Richards \& Schat. 2011).

Concerning the hypotheses outlined in the study, they not only point to theoretical contributions of attachment in labor relations, but also outline external evidence of the instrument validity (ITC, 2017; Reppold, Gurgel \& Hutz, 2014). The first hypothesis was not corroborated with the results of the present study, and no significant relationship was observed 
between avoidant attachment of WAtS and ECR, refuting (H1.1). The non-direct relationship of avoidant attachment variables reveals that the nature of items adapted from ECR (Nativity \& Shiramizu, 2015) to work not content retains elements of relationship avoidance. Avoidance attachment style is dimensional of discomfort and turn-off feelings with interpersonal domains (De Andrade et al., 2018) and although traditional studies point to the extension of the characteristics of attachment styles to different domains of individuals' lives (Harms, 2011, Hazan \& Shaver, 1990), the non-correlational results for avoidant attachment show and reinforce the importance of specific methodologies for domains of analysis. Increasing the use of adapted or developement versions of measures to assess attachament in the professional and career context (Leiter et al., 2015; Luke, Carnelley \& Sedikides, 2019).

For the anxiety dimension from both measures, the relationship was positive and moderate, a fact that corroborates (H1.2). In WAtS anxious factor, with items originally elaborated by the authors of this article, it was found that the component of dependence on others, in this case bosses and co-workers, as well as insecurity in the face of new professional challenges, closely resembles activations of fear in environment exploration (Leiter et al., 2015), as well as fear of rejection in workplace interactions (Johnstone \& Feeney, 2015).

As for the WAtS secure attachment relationship with both dimensions of ECR, this met the expected negative relationship with avoidant dimension and was positively related to the ECR's anxious dimension, which led to partial consideration of (H1.3). The relationship between secure attachment domain and insecure attachment subdomains supports the measurement nature proposed by the ECR scale (Brennan et al., 1998; Nativity \& Shiramizu, 2015). The negative relationship found with avoidance dimension meets previous theoretical assumptions, however, the positive relationship with insecure attachment is an investigation and research detail for future studies. It is important to highlight that the same type of relationship was observed with anxiety aspects measured by the already valid ECR scale.

The research findings corroborated hypothetical relationships with individual selfefficacy. In this sense, self-efficacy presented positive association with secure attachment at work and negative relationship with aspects of anxious and avoidant attachment in work relationships. These results are comparable to those from Wolfe and Betz (2004) and Kohlhoff and Barnett (2013) that found positive correlations between secure attachment and self-efficacy.

Concerning the relationship with career aspects, it was observed that no significant relationships were found with aspects of career adaptability and secure attachment, refuting (H3.1). Anxious attachment at work was negatively related to dimensions of control, curiosity and confidence. Avoidant attachment had a negative relationship with control and curiosity aspects, partially corroborating (H3.2). These results indicate that insecure attachment in relationships at the workplace, is negatively related to career adaptability traits. Pfaller, Kiselica \& Gerstein (1998) found positive correlation between secure attachment and career adaptability.

The present study aligns with a recent wave of research interested in the investigation of adult attachment themes at work (De Andrade et al., 2018; Peck \& Gumuchian, 2015; Richards $\&$ Schat, 2011; Yip et al., 2017). One of the problems of the investigations raised on the subject is the lack of measures to evaluate attachment in prototypical relationships with coworkers. The only psychometric measure with good evidence available for assessing adult job attachment was the English version of The Short Workplace Attachment Measure (SWAM) by Leiter et al. (2015). Given the complexity of the construct, a large set of indicators is necessary. In this context, the WAtS can be a good alternative, with more items and covering aspects beyond SWAM, contemplating a set of items for the evaluation of insecure attachment domains (anxiety and avoidance), as well as extra items for the dimensional of secure attachment.

In conclusion, this study offers a validated measure to evaluate attachment in workplace for this context: WAtS. The new instrument built in Portuguese enables investigating attachment relationships in the workplace in a population that have been understudied in this aspect. Further 
studies are needed to broad the complex range of relationships between workplace attachment variables and other career and work dimensions, such as job satisfaction, performance, health and well-being.

\section{References}

Albert, L. S. \& Horowitz. L. M. (2009). Attachment styles and ethical behavior: their relationship and significance in the market place. Journal of Business Ethics, 87, 299-316. doi: $1.1007 / \mathrm{s} 10551-008-9918-6$

Audibert, A. \& Teixeira. M. A. (2015). Escala de adaptabilidade de carreira: evidências de validade em universitários brasileiros [Career adaptability scale: evidences of validity in Brazilian university students]. Revista Brasileira de Orientação Profissional, 16(1), 83-93.

Blustein, D. L., Prezioso. M. S. \& Schultheiss, D. P. (1995). Attachment theory and career development: Current status and future directions. The Counseling Psychologist, 23(3), 416-432. doi: 10.1177/0011000095233002

Bolat, N. \& Odac1, H. (2016). High School Final Year Students' Career Decision-Making SelfEfficacy. Attachment Styles and Gender Role Orientations. Current Psychology, 36(2), 252-259. doi: 1.1007/s12144-016-9409-3

Bowlby, J. (1973). Attachment and loss: separation. anxiety and anger. New York. USA: Basic Books.

Brennan, K. A., Clark, C. L. \& Shaver, P. R. (1998). Self-report measurement of adult attachment: An integrative overview. In Simpson, J. A. \& Rholes W. S. (Eds.) Attachment theory and close relationships (pp. 46-76). New York: Guilford Press.

Brown, G. W., Harris. T. O. \& Craig, T. K. (2019). Exploration of the influence of insecure attachment and parental maltreatment on the incidence and course of adult clinical depression. Psychological medicine, 49(6) 1025-1032. doi: 1.1017/S0033291718001721

Byrne, Z., Albert. L., Manning, S. \& Desir, R. (2017). Relational models and engagement: an attachment theory perspective. Journal of Managerial Psychology, 32(1), 30-44. doi: 1.1108/JMP-01-2016-0006

Collins, N. L. \& Read, S. J. (1990). Adult Attachment, Working Models, and Relationship Quality in Dating Couples. Journal of Personality and Social Psychology, 58(4), 644-663. doi: 10.1037/0022-3514.58.4.644

International Test Comssion [ITC] (2017). The ITC Guidelines for Translating and Adapting Tests (Second Edition).

CONEP (2014). Resolução $\mathrm{n}^{\circ}$ 466. de 12 de dezembro de 2012. Retrieved from http://bvsms.saude.gov.br/bvs/saudelegis/cns/2013/res0466_12_12_2012.html

Conradi, H. J., Kamphuis. J. H. \& de Jonge, P. (2017). Adult attachment predicts the seven-year course of recurrent depression in primary care. Journal of Affective Disorders, 225(1), 160166. doi: 1.1016/j.jad.2017.08.009.

Costa, L. V. (2013). Construção e validação de uma escala de percepção de sucesso na carreira [Construction and validation of a career success perception scale]. Revista de Carreiras $e$ Pessoas, 3(1), 3-19. doi: 1.20503/recape.v3i1.15435

Dahling, J. J. \& Librizzi, U. A. (2015). Integrating the Theory of Work Adjustment and Attachment Theory to Predict Job Turnover Intentions. Journal of Career Development, 42(3), 215-228. doi: 10.1177/0894845314545169

De Andrade, A. L., Oliveira, M. Z., Knowles, C. M. M. H., Neto, H. C. B. \& Hatfield, E. (2018). Relational models and work-family confl ict: a study with samples from Brazil and the United States of America. Ciencias Psicológicas, 12(2), 167-176. 
Feeney, J. A. (2008). Adult romantic attachment: Developments in the study of couple relationships. In J. Cassidy \& P. R. Shaver (Eds.). Handbook of Attachment: Theory. Research and Clinical Applications (pp. 456-481). New York. USA: Guilford.

Fraley, R. C., Hudson. N. W., Heffernan, M. E. \& Segal, N. (2015). Are adult attachment styles categorical or dimensional? A taxometric analysis of general and relationship-specific attachment orientations. Journal of Personality and Social Psychology, 109(2), 354-368. doi: $1.1037 / \mathrm{pspp} 0000027$

Freitas, C. P. P. \& Damásio, B. F. (2018). Evidências de validade com base nas relações com medidas externas: conceituação e problematização. In B. F. Damásio \& J. C. Borsa (Orgs). Manual de desenvolvimento de instrumentos psicológicos (pp. 101-115). Porto Alegre: Vetor.

Gleeson, G. \& Fitzgerald, A. (2014) Exploring the association between adult attachment styles in romantic relationships. Perceptions of parents from childhood and relationship satisfaction. Health, 6, 1643-1661. doi: 10.4236/health.2014.613196

Harms, P. D. (2011). Adult attachment styles in the workplace. Human Resource Management Review, 21(4), 285-296. doi: 10.1016/j.hrmr.2010.10.006

Hayden, M. C., Müllauer, P. K. \& Andreas, S. (2017). A systematic review on the association between adult attachment and interpersonal problems. Journal of Psychology \& Psychotherapy, 7(2), 1-9. doi: 1.4172/2161-0487.1000296

Hazan, C. \& Shaver, P. R. (1990). Love and work: An attachment-theoretical perspective. Journal of Personality and Social Psychology, 59(2), 270-280. doi: 10.1037/00223514.59.2.270

Jackson, D. L., Gillaspy, J. A. \& Purc-Stephenson, R. (2009). Reporting practices in confirmatory factor analysis: An overview and some recommendations. Psychological Methods, 14(1), 6-23. doi: 10.1037/a0014694

Jiang, L. (2017). Perception of and reactions to job insecurity: The buffering effect of secure attachment. Work \& Stress, 31(3), 256-275. doi: 1.1080/02678373.2017.1305005

Johnstone, M. \& Feeney, J. A. (2015). Individual differences in responses to workplace stress: The contribution of attachment theory. Journal of Applied Social Psychology, 45(7), 412424. doi: $10.1111 /$ jasp. 12308

Kohlhoff, J. \& Barnett, B. (2013). Parenting self-efficacy: Links with maternal depression. infant behaviour and adult attachment. Early Human Development, 89(4), 249-256. doi: 1.1016/j.earlhumdev.2013.01.008

Kvitkovičová, L., Umemura, T. \& Macek, P. (2017). Roles of attachment relationships in emerging adults' career decision-making process: A two-year longitudinal research design. Journal of Vocational Behavior, 101, 119-132. doi: 1.1016/j.jvb.2017.05.006

Leiter, M. P., Day, A. \& Price, L. (2015). Attachment styles at work: Measurement, collegial relationships, and burnout. Burnout Research, 2(1), 25-35. doi: 10.1016/j.burn.2015.02.003

Leiter, M. P., Peck, E. \& Gumuchian, S. (2015). Workplace Incivility and its Implications for Well-Being. Mistreatment in Organizations (Research in Occupational Stress and Well Being), 13, 107-135. doi: 10.1108/S1479-355520150000013004

Lorenzo-Seva, U. \& Ferrando, P. J. (2013). FACTOR 9.2: A Comprehensive Program for Fitting Exploratory and Semiconfirmatory Factor Analysis and IRT Models. Applied Psychological Measurement, 37(6), 497-498. doi: 1.1177/0146621613487794

Luke, M. A., Carnelley, K. B., \& Sedikides, C. (2020). Attachments in the workplace: How attachment security in the workplace benefits the organization. European Journal of Social Psychology, 50(5), 1046-1064. doi: 10.1002/ejsp.2652

Muthén, L. K. \& Muthén, B. O. (2012). Mplus: Statistical analysis with latent variables. User's guide. Los Angeles: Muthén \& Muthén. 
Natividade, J. C. \& Shiramizu, V. K. M. (2015). An attachment measure: Brazilian version of Experiences in Close Relationship Scale-Short Form. Psicologia USP, 26(3), 484-494. doi: 1.1590/0103-656420140086

Pfaller, J., Kiselica, M. \& Gerstein, L. (1998). Attachment style and family dynamics in young adults. Journal of Counseling Psychology, 45(3), 353-357. doi: 1.1037/0022-0167.45.3.353

Phang, A., Fan, W. \& Arbona, C. (2018). Secure Attachment and Career Indecision: The Mediating Role of Emotional Intelligence. Journal of Career Development, 1-14. doi: $1.1177 / 0894845318814366$

Poncy, G., Kim, M., Ramos, K. \& Lopez, F. G. (2017). Career Planning Confidence Among Facebook Users. Journal of Career Assessment, 26(4), 599-615. doi: $1.1177 / 1069072717723094$

Ramos, K. \& Lopez, F. G. (2018). Attachment security and career adaptability as predictors of subjective well-being among career transitioners. Journal of Vocational Behavior, 104, 7285. doi: 10.1016/j.jvb.2017.10.004

Ravitz, P., Maunder, R., Hunter, J., Sthankiya, B. \& Lancee, W. (2010). Adult attachment measures: A 25-year review. Journal of Psychosomatic Research, 69(4), 419-432. doi: 0.1016/j.jpsychores.2009.08.006

Reizer, A. (2019). Bringing self-kindness into the workplace: Exploring the mediating role of self-compassion in the associations between attachment and organizational outcomes. Frontiers in Psychology, 10, 1148. doi: 1.3389/fpsyg.2019.01148

Reizer, A., Oren, L. \& Hornik, Y. (2019). Does group cohesion moderate associations between attachment, caregiving, and OCB? Journal of Management \& Organization, 1-18. doi: 10.1017/jmo.2019.25

Reppold, C. T., Gurgel, L. G. \& Hutz, C. S. (2014). O processo de construção de escalas psicométricas. Avaliação Psicológica, 13(2), 307-310.

Richards, D. A. \& Schat, A. C. H. (2011). Attachment at (Not to) Work: Applying Attachment Theory to Explain Individual Behavior in Organizations. Journal of Applied Psychology, 96(1), 169-182. doi: 10.1037/a0020372

Rindskopf, D. (2010). Latent transition analysis. In G. R. Hancock \& R. O. Mueller (Eds.) The reviewer's guide to quantitative methods in the social sciences (pp. 109-207). New York: Routledge.

Ronen, S. \& Zuroff, D. C. (2017). How does secure attachment affect job performance and job promotion? The role of social-rank behaviors. Journal of Vocational Behavior, 100, 137148. doi: $1.1016 /$ j.jvb.2017.03.006

Savickas, M. L. (2011). New questions for vocational psychology: Premises, paradigms, and practices. Journal of Career Assessment, 19(3), 251-258. doi: 10.1177/1069072710395532

Schmitt, T. A. (2011). Current methodological considerations in exploratory and confirmatory factor analysis. Journal of Psychoeducational Assessment, 29(4), 304-321. doi: $10.1177 / 0734282911406653$

Teixeira, J., Dias, A. \& Dell'Aglio, D. (2012). Propriedades Psicométricas da Escala de Autoeficácia Geral Percebida (EAGP). Psico, 43(2), 139-146.

Vîrgă, D., Schaufeli, W. B., Taris, T. W., van Beek, I. \& Sulea, C. (2018). Attachment Styles and Employee Performance: The Mediating Role of Burnout. The Journal of psychology, 153(4), 383-401. doi: 1.1080/0022398.2018.1542375

Wachelke, J., Natividade, J., De Andrade, A. D., Wolter, R. \& Camargo, B. (2014). Caracterização e avaliação de um procedimento de coleta de dados online (CORP) [Characterization and evaluation of an online data collection procedure (CORP)]. Avaliação Psicológica, 13(1). 143-146.

Wright, S. L. \& Perrone, K. M. (2008). The impact of attachment on career-related variables: A review of the literature and proposed theoretical framework to guide future research. 
Journal of Career Development, 35(2), 87-106. doi: 1.1177/0894845308325643

Wright, S. L. (2017). Attachment and Self-Efficacy in Career Search Activities: A Structural Model. The Career Development Quarterly, 65(2), 98-112. doi: 10.1002/cdq.12085

Yip, J., Ehrhardt, K., Black, H. \& Walker, D. O. (2017). Attachment theory at work: A review and directions for future research. Journal of Organizational Behavior, 39(2), 185-198. doi: 10.1002/job.2204

Zanon, C., Bardagi, M. P., Layous, K. \& Hutz, C. S. (2014). Validation of the satisfaction with life scale to Brazilians: Evidences of measurement noninvariance across Brazil and US. Social Indicators Research, 119(1), 443-453. doi: 1.1007/s11205-013-0478-5

Funding: Cnpq (The Brazilian National Council for Scientific and Technological Development), CAPES (Coordination for the Improvement of Higher Education Personnel) and Fapes (Support Foundation to Research and Innovation of Espírito Santo).

Authors' participation: a) Conception and design of the work; b) Data acquisition; c) Analysis and interpretation of data; d) Writing of the manuscript; e) Critical review of the manuscript.

A.L.D.A. has contributed in a,b,c,d,e ; P.F.P. in a,b,c,d,e.

Scientific editor in charge: Dra. Cecilia Cracco 